\title{
The analysis of the influence of stabilization conditions of working filters on the sample mass of diesel particulates
}

\begin{abstract}
The paper presents the influence of the conditioning of filters used in the gravimetric measurement of particulate matter emission on the mass of the particles. The influence of the time of filter conditioning on the obtained results as well as the influence of the temperature of the sample before the filtering on the measurement uncertainty have been subjected to analysis. In the further part the influence of the ranges of temperatures of the filter conditioning on the mass of the PM sample have been determined as per the standardization for the tests of diesel engines fitted in passenger vehicles, heavy-duty vehicles and buses (regulation $R-83$ and $R-49$ respectively). In the final part recommendations have been formulated that allow a reduction of the measurement error.
\end{abstract}

Key words: diesel engine, emissions measurements, particulate matter, accuracy of measurement

\section{Analiza wpływu warunków kondycjonowania filtrów na masę próbki cząstek stałych}

$W$ artykule przedstawiono wplyw warunków kondycjonowania filtrów używanych do pomiaru emisji cząstek stałych metoda grawimetryczna na mase próbki czastek stałych. Analizie poddano wplyw czasu kondycjonowania filtrów pomiarowych na otrzymane wyniki oraz wpływ temperatury próbki przed filtrowaniem na niepewność pomiaru. Następnie przedstawiono wpływ zakresów temperatur kondycjonowania filtrów, zgodnych z dokumentami normalizacyjnymi dla badań silników o zapłonie samoczynnym montowanych $w$ samochodach osobowych oraz ciężarowych $i$ autobusach (kolejno regulamin $R-83$ i $R$-49) na masę próbki cząstek stałych. Na zakończenie artykułu sformułowano zalecenia, pozwalajace zmniejszyć błąd pomiarowy.

Słowa kluczowe: silnik o zapłonie samoczynnym, pomiar emisji, cząstki stałe, niepewność pomiaru

\section{Introduction}

The stabilization of the working filters before their being weighed is one of the stages of the certification procedure of measuring the normalized ecological index - the mass emission of particulates (PT) with the exhaust gases (EG) of the diesel engine. At this stage the filters with the collected PT are held in a special chamber or a room during a certain time interval $-\tau_{\mathrm{st}}$ at the designed temperature $-\mathrm{t}_{\mathrm{st}}$. The permissible ranges of these parameters are set down by normative documents: in testing diesel engines of cars (according to Rules R-83 [1]) $-\tau_{\mathrm{st}}=2 \ldots 80$ hour, $\mathrm{t}_{\mathrm{st}}=22 \pm 3{ }^{\circ} \mathrm{C}$; in testing diesel engines of trucks and buses (according to Rules R-49 $[2])-\tau_{\text {st }}=2 \ldots 36$ hour, $t_{\text {st }}=(20 \ldots 30) \pm 6^{\circ} \mathrm{C}$.

The results of the research carried out by the leading firms producing the equipment for the ecological diagnostics of diesel engines show that the parameters of the stabilization process of the working filters - the values $\tau_{\mathrm{st}}$ and $\mathrm{t}_{\mathrm{st}}$ - influence the estimated values of the sample mass of PT $-m_{f}$, which results in the appearance of the methodical error in measuring the given value $-\delta \mathrm{m}^{\mathrm{st}}{ }_{\mathrm{f}}[3-5]$. Taking this error into account will enable one to reduce the uncertainty of measuring the value $m_{f}$ and to increase the accuracy of measuring mass emission of PT with EG of the diesel engine.

\section{The problem stated}

The aim of the research is to estimate the uncertainty of the result of measuring the sample mass of PT which appears as a result of its being influenced by the parameters of the

\section{Wstęp}

Kondycjonowanie filtrów pomiarowych przed ich ważeniem jest jednym $\mathrm{z}$ etapów procedury homologacyjnej pomiaru masy cząstek stałych (PM - particulate matter) w gazach wylotowych silników o zapłonie samoczynnym. Na tym etapie filtry wraz ze zgromadzonymi PM są przechowywane w specjalnej komorze lub pomieszczeniu przez określony czas $\tau_{\mathrm{st}} \mathrm{i} \mathrm{w}$ zadanej temperaturze $t_{s t}$. Dopuszczalne wartości tych parametrów są zawarte w dokumentach normalizacyjnych: dla filtrów montowanych w układach pomiarowych silników o zapłonie samoczynnym (ZS), montowanych $\mathrm{w}$ samochodach osobowych (zgodnie $\mathrm{z}$ Regulaminem $\mathrm{R}-83[1])-\tau_{\text {st }}=2-80$ godz., $\mathrm{t}_{\mathrm{st}}=22 \pm 3{ }^{\circ} \mathrm{C}$, natomiast $\mathrm{w}$ odniesieniu do filtrów stosowanych do badań silników ZS, stosowanych w samochodach ciężarowych i autobusach (zgodnie z Regulaminem R-49 [2]) $-\tau_{\mathrm{st}}=2-36$ godz., $\mathrm{t}_{\mathrm{st}}=(20-30) \pm 6{ }^{\circ} \mathrm{C}$.

Wyniki badań prowadzone przez znaczące firmy produkujące aparaturę do pomiarów emisji składników toksycznych spalin silników ZS wykazują, że parametry procesu kondycjonowania filtrów $-\tau_{\mathrm{st}} \mathrm{i}_{\mathrm{st}}-$ wpływają na szacowaną masę próbki PM - $\mathrm{m}_{\mathrm{f}}$, co skutkuje wystąpieniem błędu metodycznego w pomiarze danej wartości $-\delta \mathrm{m}^{\mathrm{st}}{ }_{\mathrm{f}}[3$ - 5]. Likwidując ten błąd, można zmniejszyć niepewność pomiaru $\mathrm{m}_{\mathrm{f}} \mathrm{i}$ zwiększyć dokładność pomiaru masy PM w gazach wylotowych silników ZS. 
stabilization processes of the working filters. The following problems have been solved to achieve the aim set:

1) the experimental data about the influence of the parameters $\tau_{\text {st }}$ and $t_{\text {st }}$ on the value $m_{f}$ have been analyzed,

2 ) the methods of estimating the error $\delta \mathrm{m}^{\text {st }}{ }_{\mathrm{f}}$ have been developed,

3) the recommendations for reducing the error $\delta m^{\text {st }}{ }_{f}$ have been given,

4) the uncertainty of the result of measuring the sample mass of PT during the certification tests of diesel engines of cars and trucks has been estimated.

\section{The analysis of the experimental data}

To estimate the influence of the parameters of the stabilization process of the working filters on the sample mass of PT, the results of the experimental research carried out by the firm Mitsubishi (Fig. 1) [3] have been used.

The data presented in Fig. 1a testify to the reduction of the relative sample mass of PT $-\mu_{f}^{\tau}$ with the increase of the duration of the stabilization period according to the logarithmic dependence. Such a change of the value $\mu_{f}^{\tau}$ is

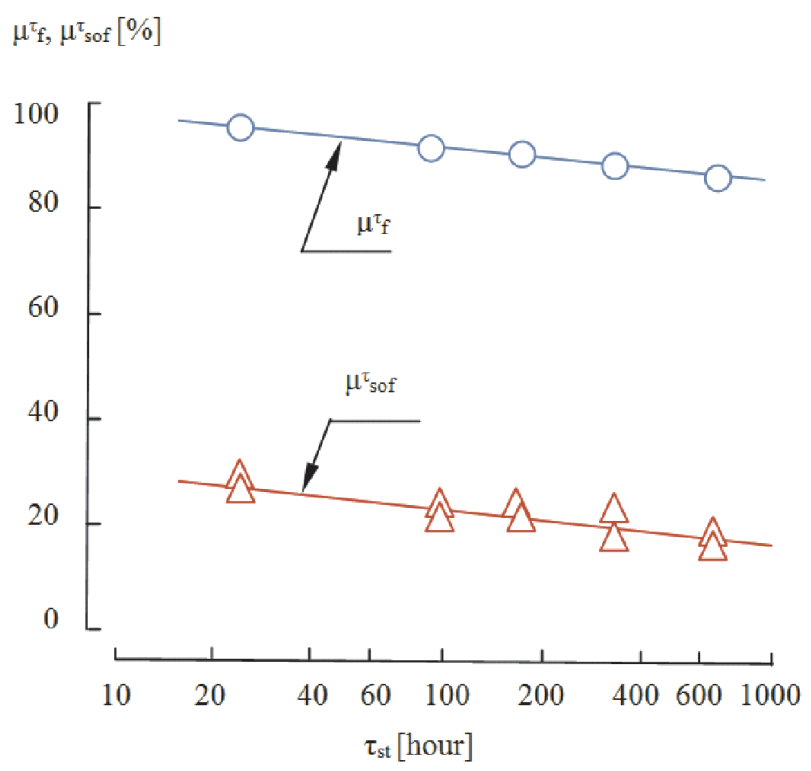

a)

\section{Określenie problemu}

Celem badań było oszacowanie niepewności wyniku pomiaru masy PM, która jest rezultatem wpływu parametrów procesu kondycjonowania filtrów pomiarowych. Aby osiągnąć wyznaczone cele, wykonano następujące czynności:

1) przeanalizowano dane dotyczące wpływu parametrów $\tau_{\mathrm{st}}$ i t $_{\text {st }}$ na wartość $m_{\mathrm{f}}$,

2) opracowano metody szacowania błędu $\delta \mathrm{m}^{\mathrm{st}}$,

3) podano zalecenia $w$ celu zmniejszenia błędu $\delta m^{\text {st }}$,

4) oszacowano niepewność pomiaru masy próbki PM w trakcie badań homologacyjnych silników ZS samochodów osobowych i ciężarowych.

\section{Analiza danych doświadczalnych}

Aby oszacować wpływ parametrów kondycjonowania filtrów pomiarowych na masę próbki PM, wykorzystano wyniki badań przeprowadzonych przez firmę Mitsubishi (rys. 1) [3].

Na podstawie analizy wyników przedstawionych na rys. 1a stwierdza się zmniejszenie względnej masy próbki $\Delta \mu^{\mathrm{t}=45_{\mathrm{f}}[\%]}$

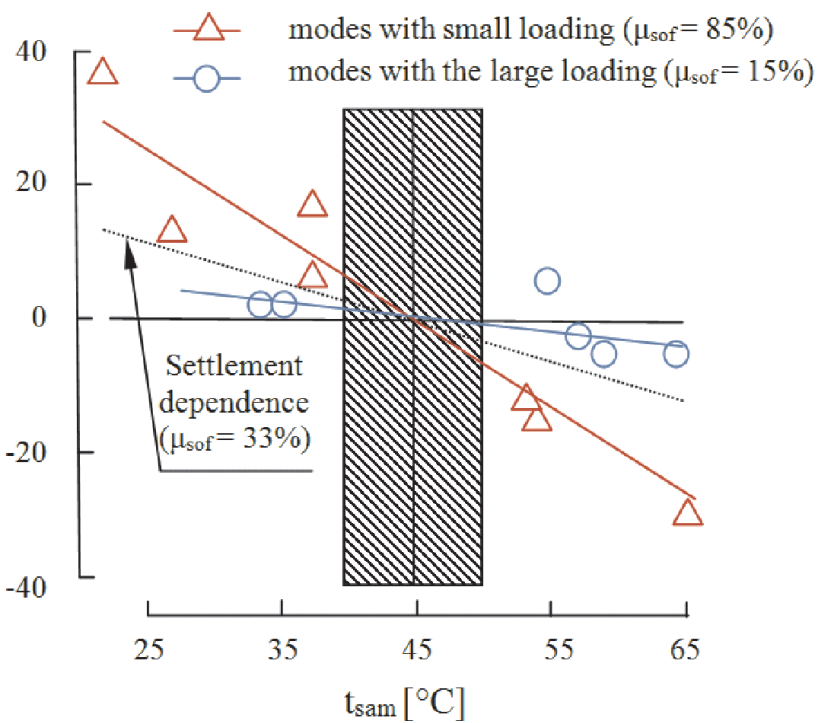

b)

Fig. 1. The experimental data about the uncertainty of results of measuring the sample mass of PT: a) the influence of $\tau_{\text {st }}$ on the relative sample mass of PT $-\mu_{\mathrm{f}}^{\tau}$ and SOF $-\mu_{\mathrm{SOF}}^{\tau}$ b) the influence of the sample temperature before the filters $\mathrm{t}_{\mathrm{sam}}$ on deviations $\Delta \mu_{\mathrm{f}}^{\tau}$.

Rys. 1. Wyniki doświadczalne niepewności pomiarów masy próbki PM: a) wpływ $\tau_{s t}$ na względna masę próbki $P M-\mu_{f}^{\tau} i$ SOF - $\mu_{\text {SOP }}^{\tau}$ b) wpływ temperatury próbki przed filtrowaniem $t_{\text {sam }}$ na odchylenie $\Delta \mu_{f}^{\tau}$

caused by reducing the quantity of soluble organic fraction (SOF) due to the evaporation of hydrocarbons from the surface of PT.

Figure 1b shows how the sample mass of PT is influenced by the temperature of the sample of the gas flowing through the filters for catching $\mathrm{PT}-\mathrm{t}$. It can be considered that in the range $\mathrm{t}_{\mathrm{sam}}=25 \pm 5^{\circ} \mathrm{C}, \mathrm{t}_{\mathrm{sam}} \approx \mathrm{t}_{\mathrm{st}}$. The experiment showed that in the modes with a small loading and a high content of SOF in PT the influence of the temperature $t_{\text {sam }}$ on the sample
$\mathrm{PM}-\mu_{\mathrm{f}}^{\tau}$ wraz ze wzrostem czasu trwania procesu kondycjonowania filtrów, przedstawionego w skali logarytmicznej. Taka zmiana $\mu_{\mathrm{f}}^{\tau}$ jest spowodowana zmniejszeniem udziału części organicznej (SOF) w PM w wyniku odparowywania węglowodorów z jej powierzchni.

Na rysunku $1 \mathrm{~b}$ przedstawiono wpływ temperatury spalin $\mathrm{t}_{\text {sam }}$ przepuszczonych przez filtr na masę PM zatrzymanych na filtrze. Można przyjąć, że dla $\mathrm{t}_{\mathrm{sam}}=25 \pm 5^{\circ} \mathrm{C}, \mathrm{t}_{\mathrm{sam}} \approx \mathrm{t}_{\mathrm{st}}$. Badania wykazały, że przy małej ilości PM z dużym udziałem SOF 
mass of PT was more essential than in the modes with a large loading and a low content of SOF in PT.

Having executed the transition from the logarithmic scale of the value $\tau_{\text {st }}$ to the uniform one (Fig. 1a) we will obtain the value of the initial function $\mu_{\mathrm{f}}^{\tau}\left(\tau_{\mathrm{st}}\right)$ :

$$
\mu_{\mathrm{f}}^{\tau}=100-5.15 \cdot \lg \left(\frac{\tau}{2}\right)
$$

Differentiating the given dependence we will obtain the expression for the speed of changing the relative sample mass of PT (Fig. 2):

$$
\frac{\mathrm{d} \mu_{\mathrm{f}}^{\tau}}{\mathrm{d} \tau}=-2.24 \frac{1}{\tau}
$$

The analysis of the expressions (1) and (2) shows that the sample mass of PT measured at $\tau_{\mathrm{st}}=2$ hour, decreases with the increase of the duration of the filters stabilization period: at $\tau_{\text {st }}=10$ hour - by $3.6 \%$ (at a speed of $1.1 \ldots 0.2 \%$ /hour); at $\tau_{\text {st }}=36$ hour - by $6.4 \%$ (at a speed of $0.2 \ldots 0.06 \% /$ hour); at $\tau_{\mathrm{st}}=80$ hour - by $8.2 \%$ (at a speed of $0,06 \ldots 0.03 \% /$ hour). As this takes place, beginning with $\tau_{\mathrm{st}}=20$ hours and more, the speed of reducing the sample mass of PT doesn't exceed $0.1 \%$ /hour.

Using the data about the content of SOF in PT, obtained during the certification test of the diesel engine (Fig. 1a) $-\mu_{\text {sof }}$ $=33 \%$, as well as the assumption about the proportionality of the value and the angular factor reflecting the influence of $\mathrm{t}_{\text {sam }}$ on $\Delta \mu_{\mathrm{f}}^{\mathrm{t}}$ (Fig. 1b), we will obtain the designed dependence for estimating the influence of temperature $t_{\text {sam }}$ on the sample mass of PT:

$$
\Delta \mu_{\mathrm{f}}^{\mathrm{t}=45}=\mathrm{k}_{45} \cdot\left(\mathrm{t}_{\mathrm{sam}}-45^{\circ} \mathrm{C}\right)
$$

where $\mathrm{k}_{45}=-0.55$ is the angular factor corresponding to $\mu_{\mathrm{sof}}=$ of $33 \%$ and to the temperature of comparison $\mathrm{t}_{\mathrm{sam}}=45^{\circ} \mathrm{C}$.

\section{The methods of estimating the uncertainty of the sample mass of PT}

The methodical error of measuring the sample mass of PT is regarded as the sum of two components taking into account the influence of the duration and temperature of the filters stabilization process on $\mathrm{m}_{\mathrm{f}}$ :

$$
\delta m_{f}^{s t}=\Delta \mu_{f}^{\tau}+\Delta \mu_{f}^{t}
$$

The value $\Delta \mu_{\mathrm{f}}^{\tau}$ is calculated from the formula:

$$
\Delta \mu_{\mathrm{f}}^{\tau}=\mu_{\mathrm{f}}^{\tau}-100=-5.15 \cdot \lg \frac{\tau}{2}
$$

To calculate the value $\Delta \mu_{\mathrm{f}}^{\mathrm{t}}$ the dependence (Fig. 3) is used:

$$
\Delta \mu_{\mathrm{f}}^{\mathrm{t}}=\mathrm{k}_{\mathrm{t} 0}\left(\mathrm{t}-\mathrm{t}_{0}\right)
$$

zgromadzonych na filtrze wpływ temperatury $\mathrm{t}_{\text {sam }}$ na masę próbki PM jest bardziej istotny niż przy zgromadzeniu dużej ilości PM z małym udziałem SOF.

Gdy zamieniono skalę logarytmiczną wartości $\tau_{\text {st }}$ na liniową (rys. 1a), otrzymano wartość początkową funkcji $\mu_{\mathrm{f}}^{\tau}\left(\tau_{\mathrm{st}}\right)-$ wzór $(1)$.

Różniczkowanie otrzymanej zależności pozwoli uzyskać zależność (2) na prędkość zmian względnej masy próbki PM (rys. 2).

Analiza wzorów (1) i (2) wykazuje, że masa próbki PM zmierzona $\mathrm{w}$ chwili $\tau_{\mathrm{st}}=2$ godz. maleje wraz $\mathrm{z}$ upływem czasu kondycjonowania filtra: dla $\tau_{\mathrm{st}}=10$ godz. - o 3,6\% (z szybkością 1,1 .. 0,2\%/godz.); dla $\tau_{\text {st }}=36$ godz. - o 6,4\% ( z szybkością 0,2 ... 0,06\%/godz.); dla $\tau_{\text {st }}=80$ godz. - o $8,2 \%$ (z szybkością $0,06 \ldots 0,03 \%$ /godz.). Po upływie 20 godz. ubytek masy PM nie przekracza $0,1 \%$ /godz.

Po wykorzystaniu danych dotyczących zawartości SOF w PM, otrzymanych podczas badań homologacyjnych silnika o zapłonie samoczynnym (rys. 1 a) $-\mu_{\text {sof }}=33 \%$, a także przyjęciu założenia o proporcjonalności wartości oraz współczynnika nachylenia odzwierciedlającego wpływ $t_{\text {sam }}$ na $\Delta \mu_{\mathrm{f}}^{\mathrm{t}}$ (rys. 1 b), otrzymano zależności do określenia wpływu temperatury $\mathrm{t}_{\text {sam }}$ na masę próbki PM - wzór (3), gdzie: $\mathrm{k}_{45}=$ $-0,55$ jest współczynnikiem nachylenia, któremu odpowiada $\mu_{\text {sof }}=33 \%$ i t $_{\text {sam }}=45^{\circ} \mathrm{C}$.

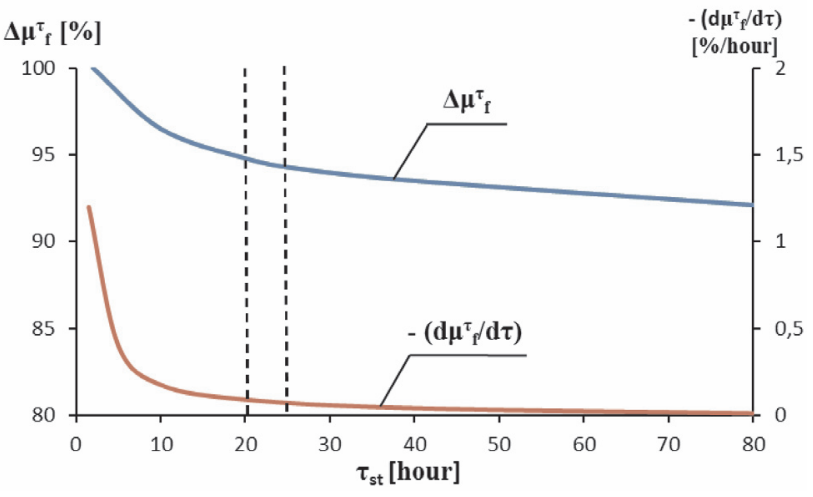

Fig. 2. The initial function $\mu_{\mathrm{f}}^{\tau}\left(\tau_{\mathrm{st}}\right)$ and its derivative Rys. 2. Funkcja pierwotna $\mu_{f}^{\tau}\left(\tau_{s}\right)$ i jej pochodna

\section{Metody szacowania niepewności masy próbki PM}

Za błąd metody pomiarowej masy próbki PM jest uważana suma dwóch składników: czasu i temperatury kondycjonowania filtrów, które wpływają na $\mathrm{m}_{\mathrm{f}}-$ wzór (4).

Wartość $\Delta \mu_{\mathrm{f}}^{\tau}$ jest obliczana z zależności (5).

Aby obliczyć wartość $\Delta \mu_{\mathrm{f}}^{\mathrm{t}}$, używana jest zależność (6) (rys. 3), gdzie: $\mathrm{k}_{\mathrm{t} 0}$ jest współczynnikiem proporcjonalności, $\mathrm{t}_{0}$ jest nastawioną temperaturą procesu kondycjonowania filtrów: zgodnie z wymaganiami Regulaminu R-83 wynosi $22{ }^{\circ} \mathrm{C}$, natomiast według Regulaminu R-49 temperatura ta powinna mieścić się w zakresie $20-30{ }^{\circ} \mathrm{C}$.

Wartość współczynnika $\mathrm{k}_{\mathrm{t} 0}$ jest obliczana $\mathrm{z}$ zależności (7). 
a)

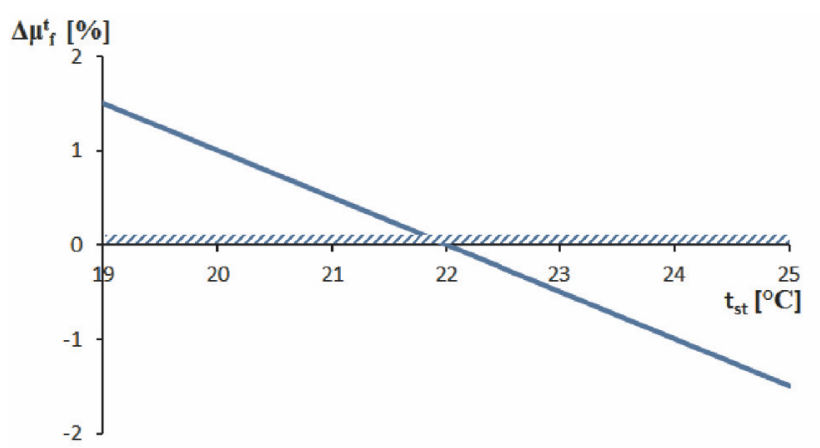

b)

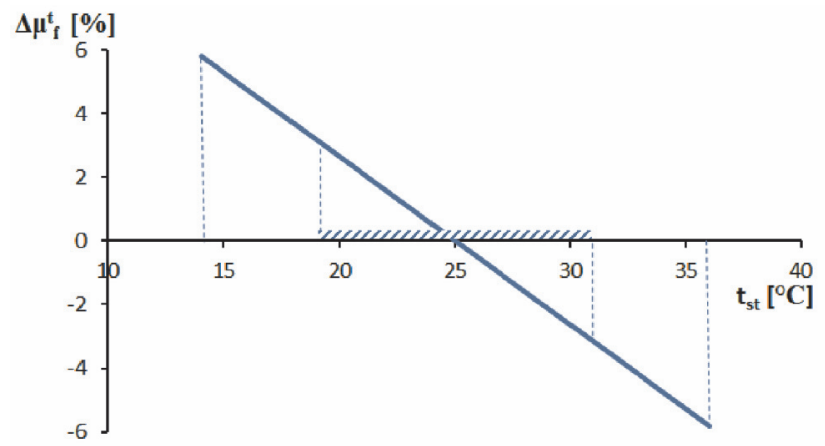

Fig. 3. The influence of the temperature $\mathrm{t}_{\mathrm{st}}$ on the sample mass of PT: a) in the range $\left.\mathrm{t}_{\mathrm{st}}=22 \pm 3{ }^{\circ} \mathrm{C}, \mathrm{b}\right)$ in the range $\mathrm{t}_{\mathrm{st}}=(20 \ldots 30) \pm 6{ }^{\circ} \mathrm{C}$ Rys. 3 Wplyw temperatury $t_{s t}$ na masę próbki PM: a) w przedziale $t_{s t}=22 \pm 3{ }^{\circ} \mathrm{C}$, b) $\mathrm{w}_{\text {przedziale }} t_{s t}=(20-30) \pm 6{ }^{\circ} \mathrm{C}$

where $\mathrm{k}_{\mathrm{t} 0}$ is the proportionality factor; $\mathrm{t}_{0}$ is the set temperature of the filters stabilization: according to the requirements of Rules R-83 it is $22{ }^{\circ} \mathrm{C}$; according to the requirements of Rules R-49 the working temperature is in the range $20 \ldots$ $30{ }^{\circ} \mathrm{C}$. sion:

The value of factor $\mathrm{k}_{\mathrm{t} 0}$ is calculated from the expres-

$$
\mathrm{k}_{\mathrm{t} 0}=\frac{\mathrm{k}_{45}}{0.01 \cdot \mathrm{k}_{45}\left(\mathrm{t}_{0}-45\right)+1}
$$

\section{The authors' recommendations for reducing $\delta \mathrm{m}^{\text {st }}{ }_{\mathrm{f}}$. The results of the research}

The analysis of the experimental data obtained by the firm Mitsubishi shows that the error $\delta \mathrm{m}^{\text {st }}{ }_{\mathrm{f}}$ can be essentially reduced. For this purpose the authors of the article recommend to reduce the ranges of the parameters variations $\tau_{\mathrm{st}}$ and $\mathrm{t}_{\mathrm{st}}$ to the intervals: $\tau_{\mathrm{st}}=22 \pm 2$ hour and $\mathrm{t}_{\mathrm{st}}=22 \pm 1^{\circ} \mathrm{C}$. The results of estimating the error $\delta \mathrm{m}^{\text {st }}{ }_{\mathrm{f}}$ by the method described above show that (Fig. 4):

- when the values $\tau_{\text {st }}$ and $t_{\text {st }}$ conform to the requirements of Rules R-83, the spread in the values of the sample mass of PT is $12.2 \%$ : $\delta \mathrm{m}_{\mathrm{f}}^{\mathrm{st}}=-10.7 \ldots 1.5 \%$,
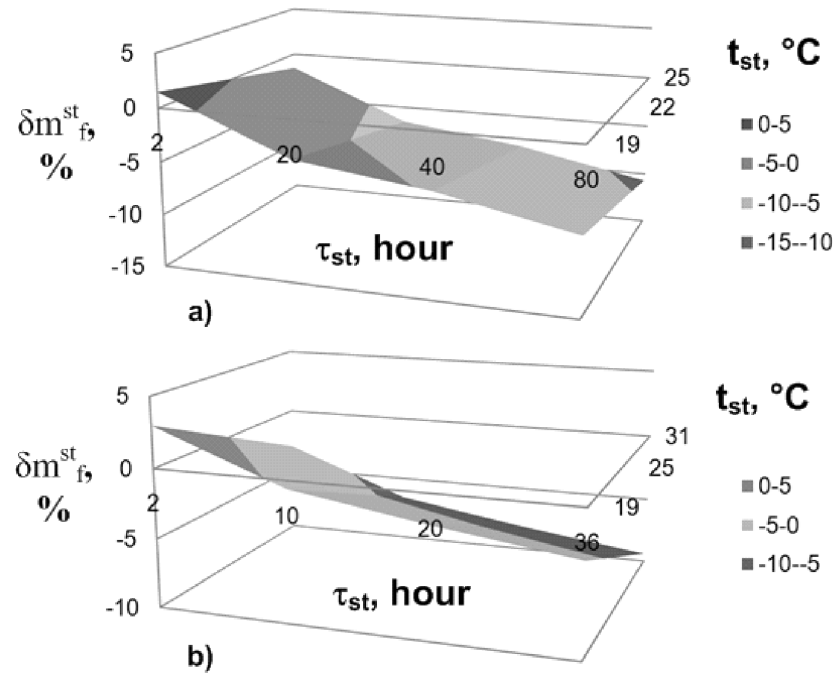

\section{Zalecenia w celu zmniejszenia $\delta m^{\text {st }}{ }_{f^{*}}$ Wyniki badań}

Analiza wyników badań uzyskanych przez firmę Mitsubishi wykazała, że błąd $\delta m^{\text {st }}{ }_{\mathrm{f}}$ można znacząco zmniejszyć. W tym celu autorzy artykułu zalecają ograniczenie zakresu zmian parametrów $\tau_{\mathrm{st}} \mathrm{i} \mathrm{t}_{\mathrm{st}}$ do przedziałów: $\tau_{\mathrm{st}}=22 \pm 2$ godz. $\mathrm{i}$ $\mathrm{t}_{\mathrm{st}}=22 \pm 1^{\circ} \mathrm{C}$. Wyniki szacowania błędu $\delta \mathrm{m}^{\text {st }}{ }_{\mathrm{f}}$ metodą opisaną Wcześniej pozwalają sformułować następujące spostrzeżenia (rys. 4):

- gdy wartości $\tau_{\mathrm{st}} \mathrm{it}_{\mathrm{st}}$ są zgodne z wymaganiami Regulaminu $\mathrm{R}-83$, różnice $\mathrm{W}$ masie próbek PM wynoszą $12,2 \%$ : $\delta \mathrm{m}_{\mathrm{f}}^{\mathrm{st}}$ $=-10,7 \div 1,5 \%$,

- gdy wartości $\tau_{\mathrm{st}} \mathrm{it}_{\mathrm{st}}$ są zgodne z wymaganiami Regulaminu $\mathrm{R}-49$, różnice $\mathrm{W}$ masie próbek PM wynoszą $12,4 \%$ : $\delta \mathrm{m}_{\mathrm{f}}^{\mathrm{st}}$ $=-9,4 \div 3,0 \%$,

- gdy wartości $\tau_{\mathrm{st}} \mathrm{it}_{\mathrm{st}}$ mieszczą się $\mathrm{w}$ zalecanych przedziałach, różnice w masie próbek PM są mniejsze o 8,8\% i wynoszą $1,4 \%$ : $\delta \mathrm{m}_{\mathrm{f}}^{\text {st }}=-0,7 \div 0,7 \%$.

\section{Wnioski}

1. Niepewność wyniku pomiaru masy próbki PM w badaniach silników o zapłonie samoczynnym przeznaczonych do samochodów osobowych wynosi 12,2\% (wymagania

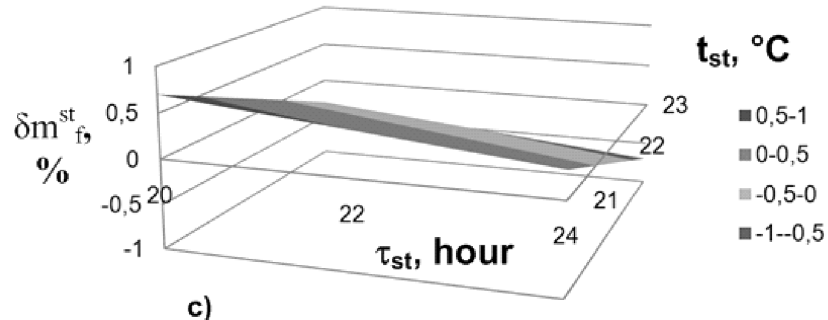

Fig. 4. The estimation of the methodical error $\delta m^{\text {st }}$ : a) in testing cars $(\mathrm{R}-83), \mathrm{b})$ in testing trucks (R-49), c) in testing in accordance with the recommendations made

Rys. 4. Oszacowanie błędu metody $\delta m_{f}^{s t}$ : a) w badanych samochodach osobowych (R-83), b) w badanych samochodach ciężarowych (R-49), c) $w$ badaniach prowadzonych zgodnie z zaproponowanymi zaleceniami 
- when the values $\tau_{\text {st }}$ and $t_{\text {st }}$ conform to the requirements of Rules R-49, the spread in the values of the sample mass of PT is $12.4 \%: \delta \mathrm{m}_{\mathrm{f}}^{\mathrm{st}}=-9.4 \ldots 3.0 \%$,

- when the parameters $\tau_{\mathrm{st}}$ and $\mathrm{t}_{\mathrm{st}}$ vary in the recommended ranges, the spread in the values of the sample mass of PT is reduced by a factor of 8.8 and is equal to $1.4 \%: \delta \mathrm{m}_{\mathrm{f}}^{\text {st }}=$ $-0.7 \ldots 0.7 \%$.

\section{Conclusions}

1. The uncertainty of the result of measuring the sample mass of PT is as follows: in testing diesel engines of cars (the requirements of Rules R-83: $\tau_{\mathrm{st}}=2 \ldots 80$ hour, $\mathrm{t}_{\mathrm{st}}=$ $22 \pm 3{ }^{\circ} \mathrm{C}$ ) $-12.2 \%$; in testing diesel engines of trucks (the requirements of Rules R-49: $\tau_{\mathrm{st}}=2 \ldots 36$ hour, $\mathrm{t}_{\mathrm{st}}=(20$ ... 30) $\left.\pm 6{ }^{\circ} \mathrm{C}\right)-12.4 \%$.

2. As a result of the reduction of the permissible ranges of varying the temperature $-t_{\mathrm{st}}$ and the duration $-\tau_{\mathrm{st}}$ of the stabilization process of filters to the intervals recommended by the authors $\left(\mathrm{t}_{\mathrm{st}}=22 \pm 1^{\circ} \mathrm{C}\right.$ and $\tau_{\mathrm{st}}=22 \pm 2$ hour $)$ the uncertainty of the result of measuring the sample mass of PT has been reduced to $1.4 \%$, i.e. by a factor of 8.8 .
Regulaminu R-83: $\tau_{\text {st }}=2 \div 80$ godz., $\mathrm{t}_{\mathrm{st}}=22 \pm 3{ }^{\circ} \mathrm{C}$ ); w badaniach silników o zapłonie samoczynnym przeznaczonych do samochodów ciężarowych $12,4 \%$ (wymagania Regulaminu R-49: $\tau_{\mathrm{st}}=2 \div 36$ godz., $\mathrm{t}_{\mathrm{st}}=20 \div 30$ $\left.\pm 6^{\circ} \mathrm{C}\right)$.

2. W wyniku ograniczenia dopuszczalnych zmian temperatury $-\mathrm{t}_{\mathrm{st}} \mathrm{i}$ czasu trwania $-\tau_{\mathrm{st}}$ procesu kondycjonowania filtrów do wartości zaproponowanych przez autorów $\left(\mathrm{t}_{\mathrm{st}}=22 \pm 1{ }^{\circ} \mathrm{C}\right.$ i $\tau_{\mathrm{st}}=22 \pm 2$ godz. $)$ niepewność wyniku pomiaru masy próbki PM została zredukowana o 1,4\%, tj. o współczynnik 8.8 .

Paper reviewed/Artykut recenzowany

\section{Abbreviation/Skróty}

$\mathrm{m}_{\mathrm{f}} \quad$ values of the sample mass/szacowana masa próbki

$\tau_{\text {st }} \quad$ time/czas

$\mathrm{t}_{\mathrm{st}} \quad$ temperature/temperatura

$\mu_{\mathrm{f}}^{\mathrm{t}} \quad$ relative sample mass/względna masa próbki

$\mu_{\mathrm{f}}^{\tau} \quad$ relative time of sample conditioning/względny czas kondycjonowania próbki
$\Delta \mu_{\mathrm{f}}^{\mathrm{t}} \quad$ deviation of relative time of sample conditioning/odchylenie względnego czasu kondycjonowania próbki

$\Delta \mu_{\mathrm{f}}^{\tau} \quad$ deviation of relative sample mass/odchylenie masy próbki

$\delta \mathrm{m}^{\mathrm{st}}{ }_{\mathrm{f}} \quad$ methodical error/bład metodyczny

\section{Bibligraphy/Literatura}

[1] Regulation No 83. Revision 2. Uniform provision concerning the approval of vehicles with regard to the emission of pollutants according to engine fuel requirements. The 05 series of amendments - United Nations Economic and Social Council Economic Commission for Europe Inland Transport Committee Working Party on the Construction of Vehicles. - E/ECE/ TRANS/505. - 30 October 2001, p. 216.

[2] Regulation No 49. Revision 2. Uniform provision concerning the approval of compression ignition (C.I.) engines and vehicles equipped with C.I. engines with regard to the emissions of pollutants by the engine. - United Nations Economic and Social Council Economic Commission for Europe Inland Transport Committee Working Party on the Construction of Vehicles. - E/ ECE/TRANS/505, p. 61.

Andrey Polivyanchuk, DEng. - associate professor in Ecology Department of East Ukraine Volodymyr Dahl National University, Lugansk, Ukraine. Dr inż. Andrey Polivyanchuk - docent na Wschodnio-Ukraińskim Narodowym Uniwersytecie im. Wtadimira Dalii, Wydziat Ekologii, Lugańsk, Ukraina. e-mail: apmail@meta.ua

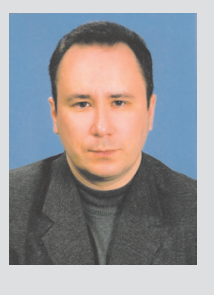

[3] Nobuyoshi H., Izumi F., Taceshi S.: Measurement of diesel exhaust emissions with mini-dilution tunnel // SAE Techn. Pap. Ser. - 1989. - No 890181, p. 12.

[4] Smart Sampler PC SPC 472. Operating Manual. Diesel particulate dilution and sampling equipment. AVL, Austria, 1993, p. 69.

[5] Engeljehringer K., Schindler W., Sulzer. Meeting ISO 8178 Requirements for the Measurement of Diesel Particulates with Partial-Flow Dilution Systems. SAE Technical Paper Series 932466, 1993, p. 10.

Oleg Ignatov, DEng. - East-Ukrainian National University of the Volodymyr Dahl, Department of Ecology, Lugansk, Ukraine.

Dr inż. Oleg Ignatov - docent na Wschodnio-Ukraińskim Narodowym Uniwersytecie im. Wtadimira Dalii, Wydziat Ekologii, Lugańsk, Ukraina. e-mail: uni@snu.edu.ua

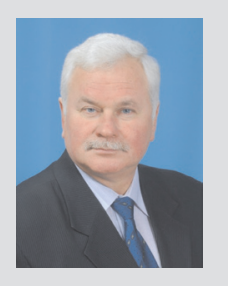

